\title{
PD-1 function in apoptosis of T lymphocytes in canine visceral leishmaniasis
}

\author{
Vanessa Marim Chiku ${ }^{a}$, Kathlenn Liezbeth Oliveira Silva ${ }^{a}$, \\ Breno Fernando Martins de Almeida ${ }^{\mathrm{a}}$, Gabriela Lovizutto Venturin ${ }^{\mathrm{a}}$, \\ Aline Aparecida Correa Leal ${ }^{a}$, Cleber Costa de Martini ${ }^{a}$, Flavia de Rezende Eugênio ${ }^{b}$, \\ Paulo Sergio Patto dos Santos ${ }^{\mathrm{b}}$, Valéria Marçal Felix de Lima ${ }^{\mathrm{b}, *}$ \\ a Faculty of Veterinary Medicine of Araçatuba, Universidade Estadual Paulista, “Julio de Mesquita Filho", FMVA/UNESP, Rua Clovis Pestana, 793, Araçatuba, \\ São Paulo CEP 16050-680, Brazil, \\ ${ }^{\mathrm{b}}$ Department of Clinical Care, Surgery and Animal Reproduction, Laboratory of Cellular Immunology, Faculty of Veterinary Medicine of Araçatuba, \\ Universidade Estadual Paulista, “Julio de Mesquita Filho”, FMVA/UNESP, Rua Clovis Pestana, 793, Araçatuba, São Paulo CEP 16050-680, Brazil
}

\section{A R T I C L E I N F O}

\section{Article history:}

Received 27 November 2015

Received in revised form 2 March 2016

Accepted 17 March 2016

Available online 18 March 2016

\section{Keywords:}

Canine visceral leishmaniasis

PD-1 (programmed cell death 1)

Apoptosis

\begin{abstract}
A B S T R A C T
Dogs infected with Leishmania infantum have a reduced number of T lymphocytes. PD-1 (Programmed cell death 1) a new member of the B7-CD28 family that is expressed by immune cells, and its binding to PD-L1 (CD274) or PD-L2 (CD273) induces the deactivation or apoptosis of T cells. This study aimed to evaluate the expression of PD-1 and its ligands, as well as blocking in the induction of apoptosis in Tlymphocytes, TNF- $\alpha$, IL- 4 and nitric oxide production by leucokocytes from PBMC and spleen and the parasite load in dogs with visceral leishmaniasis (VL). Our results showed that the expression of PD1 and its ligands was increased in $\mathrm{CD}^{+} \mathrm{T}$ cells and $\mathrm{CD} 21^{+} \mathrm{B}$ lymphocytes within the peripheral blood and splenic mononuclear cells of dogs with VL. In peripheral blood monocytes, only PD-1 ligands exhibited increased expression; however, in spleen macrophages, increased expression of both PD-1 and its ligands was observed. Levels of apoptosis in peripheral blood and splenic T lymphocytes were higher in dogs with VL compared to healthy dogs. Blocking monoclonal antibodies to PD-1 and its ligands in the culture of mononuclear cells from the peripheral blood and spleen decreased the amount of $\mathrm{CD}^{+} \mathrm{T}$ lymphocyte apoptosis. The concentration of nitric oxide, TNF- $\alpha$ and IL- 4 increased in the culture supernatants of peripheral blood mononuclear cells treated with a blocking monoclonal antibody against PD- 1 . The TNF- $\alpha$ concentration increased in the culture supernatants of splenic cells following all treatments with antibodies blocking PD-1 and its ligands; however, the amount of IL-4 increased only in the presence of a PD- 1 blocking agent. Treatment with a PD-1 blocking monoclonal antibody in the mononuclear peripheral blood of dogs with VL reduced the parasite burden while increased TNF- $\alpha$. We conclude that in canine visceral leishmaniasis, PD-1 and its ligands are involved in the induction of T lymphocyte apoptosis and in regulating the production of nitric oxide, TNF- $\alpha$, and IL-4, as well as the parasitic load.
\end{abstract}

(c) 2016 Elsevier GmbH. All rights reserved.

\section{Introduction}

Visceral leishmaniasis (VL) is considered one of the most important parasitic zoonoses expanding throughout the world, with over 186 million people being at risk of infection, affecting children and \footnotetext{
niasis.

* Corresponding author.

E-mail address: vmflima@fmva.unesp.br (V.M.F. de Lima).
}

Abbreviations: IL, interleukins; TNF, tumor necrosis factor; VL, visceral leishma- young adults in 88 countries and on every continent. Considered by the World Health Organization (WHO) among the six major tropical diseases, the absence of treatment causes the death of $30 \%$ of infected individuals, and approximately 50,000 victims of parasite infection die annually (WHO, 2010). Between 2003-2007, an increased annual incidence from an estimated 4200 to 6300 cases of VL was reported in Brazil, while there was an increase in the estimated annual incidence from 202,200 to 389,100 cases of VL (Alvar et al., 2012).

Canine visceral leishmaniasis (CVL) cases have been associated with an increase in the number of human cases (Coura-Vital et al., 
2011; Nunes et al., 2010), and the intense cutaneous parasitism in canine reservoirs facilitates infection vectors (Verçosa et al., 2012). In dogs, the suppression of cellular immunity is the most important aspect in the pathogenesis and progression of the disease. The lack of response of T lymphocytes to Leishmania antigen spp. is observed in vivo with a negative Montenegro test (Dos-Santos et al., 2008). Dogs infected with Leishmania infantum have a reduced number of T lymphocytes (Bourdoiseau et al., 1997) and a disruption of the splenic white pulp (Santana et al., 2008).

Chronic illness in dogs leads to high $\mathrm{T}$ lymphocyte apoptosis rates in the spleen and peripheral blood; this mechanism could contribute to the disruption of the white pulp of the spleen and the reduction of $\mathrm{T}$ lymphocyte levels in the peripheral blood (Lima et al., 2012). In CVL, protective immunity has been generally associated with a cellular immune response manifested by a positive lymphoproliferative response to Leishmania antigen spp. (Cabral et al., 1992).

Macrophages play an important role in the immune response against Leishmania spp.; in addition to being the parasitized cells, they are also responsible for the adaptive imune response. Costimulatory signals have been described as important regulators of the adaptive response, generating cytotoxic functions, memory or anergy induction (Pentcheva-Hoang et al., 2007). The costimulatory molecules involved in the response to Leishmania belong to the B7-CD28 family, which transmit activating (CD28) or inhibitory (CTLA-4) signals to T cells (Greenwald et al., 2005). In canine macrophages infected with Leishmania spp., failure occurs in the antigen presentation process, and analysis of the expression of costimulatory molecules indicates decreased expression of B7, which reduces the proliferation of T lymphocytes (Pinelli et al., 1999) and decreases nitric oxide production (Diaz et al., 2012).

A co-stimulatory molecule with negative function has recently been described. PD-1 (programmed cell death 1 ), or CD279, is a new member of the B7-CD28 family that is expressed by immune cells (Sharpe et al., 2007). When PD-1 is associated with its ligands PDL1 (CD274) or PD-L2 (CD273), an inhibitory tyrosine-containing sequence in $\mathrm{PD}-1$ recruits phosphatases to the molecule's tail that induce the deactivation of T lymphocytes or the induction of apoptosis, or even other responses that are important for maintaining the balance between the development of immunity, tolerance and immunopathology (Pardoll, 2012). The PD1 molecule is highly expressed in chronic infections (McNab et al., 2011), which can suppress the effector function of $\mathrm{CD}^{+} \mathrm{T}$ cells (Day et al., 2006; Trautmann et al., 2006) and $\mathrm{CD}^{+}{ }^{+}$cell secretion of the cytokine TNF- $\alpha$ (Zhang et al., 2010; D'Souza et al., 2007) and lead to immune dysfunction (D'Souza et al., 2007). Furthermore, cytokines such as IFN- $\gamma$ and TNF- $\alpha$ are produced in large quantities in response to T. cruzi infection and play a role in the production of nitric oxide and death of the parasite (Silva et al., 1995), and PD-L1 expression in uninfected mouse macrophages can control the production of nitric oxide (Yamazaki et al., 2005).

PD-L1 is more broadly expressed than PD-L2 and is induced by IFN- $\gamma$, whereas PD-L2 expression is more restricted to dendritic cells and macrophages is induced by IL- 4 and IL-13. Studies suggest that PD-L1 expression can preferentially regulate the Th1 response, whereas PD-L2 can regulate the Th2 response (Loke and Allison, 2003; Lázár-Molnár et al., 2008). Therefore, PD-L1 and PD-L2 function may depend on the microenvironmental tissue and cytokines (Dulgerian et al., 2011). However, only one study in dogs evaluated PD-1 expression in CD4 ${ }^{+}$and $C D 8^{+}$cells during VL (Esch et al., 2013).

In an experimental model of sepsis in mice, PD-L1 blocking antibodies decreased the apoptosis of $\mathrm{T}$ lymphocytes in the spleen, indicating that PD-L1 blockade may inhibit T cell apoptosis (Zhang et al., 2010). In humans, apoptosis of antigen-specific T cells was associated with increased PD-L1 expression in tumor cells (Dong et al., 2002), and PD-L1 expression on the surface of human hep- atocytes was identified as a mediator of T lymphocyte apoptosis (Muhlbauer et al., 2006).

In CVL, PD-1/PD-L1 blockade in adherent cells restored the proliferation of $\mathrm{CD}^{+}$and $\mathrm{CD} 8^{+}$lymphocytes from the peripheral blood (Esch et al., 2013). However, the involvement of PD-1 receptors and their ligands in cell apoptosis and inflammatory mediators has not been thoroughly investigated. Thus, this study aimed to evaluate the role of PD- 1 and its ligands in regulating T cell apoptosis and the production of nitric oxide, TNF- $\alpha$ and IL-4, as well as the influence on the parasitic load, in dogs with symptomatic VL. Our study clarifies aspects of $\mathrm{T}$ lymphocyte apoptosis and disease pathogenesis in dogs symptomatic for VL, which may be useful in preventive and therapeutic strategies that could reduce the incidence of leishmaniasis in dogs.

\section{Materials and methods}

\subsection{Approval of the ethics committee}

This study was approved by the Research Ethics Committee of Experimental Animals (COBEA), with the approval of the Ethics Committee on Animal Use (CEUA) of UNESP - Universidade Estadual Paulista "Julio de Mesquita Filho" - Campus Araçatuba Faculty of Veterinary Medicine - FMVA - on 15/04/2011, as case $00679 / 2011$.

\subsection{Animals}

We selected 20 adult dogs with visceral leishmaniasis (VL) between two and five years old, of various breeds and weights. The dogs were from the Araçatuba Zoonosis Control Center and were seropositive for L. infantum by indirect ELISA (Lima et al., 2003). All dogs were symptomatic and had at least three of the following clinical signs of VL: onychogryphosis, lymphadenopathy, hepatomegaly and splenomegaly, cachexia, alopecia, skin and periocular injuries. Dogs with VL showed moderate-stage disease and were classified based on a physical examination and on the levels of anti-leishmania antibodies, as determined by indirect ELISA (Lima et al., 2003), as proposed by (Solano-Gallego et al., 2009).

To control the group composition, 10 clinically healthy dogs ( 6 females and 4 males with an average age of 3.4 years) were selected using hematological, biochemical plasma analysis (albumin, aminotransferase-ALT alanine, aspartate aminotransferase, AST, total bilirubin, direct and indirect, calcium, total cholesterol, kinase CK creatine, creatinine, alkaline-FA phosphatase, phosphorus, gamma glutamyl transferase, GGT, glucose, globulins, lactate dehydrogenase, $\mathrm{LDH}$, total protein, triglycerides and urea) and type I urinalysis. All results had an optical density (OD) compatible with non-reactive animals in serology by ELISA for the diagnosis of CVL (Lima et al., 2003). These dogs were followed clinically and were monitored by serological examination at least three months before the experimente; Leishmania spp. DNA was not detected in their spleen and bone marrow samples by q-PCR (Perosso et al., 2014).

\subsection{Sample collection}

Dogs with VL were euthanized with intravenous barbiturate anesthesia (thiopental, Cristália Itapira, SP) followed by an infusion of potassium chloride according to state law. After euthanasia, spleen fragments were collected and maintained in RPMI-1640 (Sigma, St. Louis, MO, USA) supplemented with inactivated 10\% fetal bovine serum (FBS) (Gibco, Waltham, MA, USA), 0.03\% Lglutamine (Sigma, St. Louis, MO, USA), $100 \mathrm{IU} / \mathrm{mL}$ penicillin (Sigma, St. Louis, MO, USA) and $100 \mathrm{mg} / \mathrm{mL}$ streptomycin (Sigma, St. Louis, MO, USA). The control group spleen samples were obtained by sur- 
gical excision using a previously described protocol (Lima et al., 2012).

Blood samples $(10 \mathrm{~mL})$ were obtained by jugular vein puncture and placed into tubes containing sodium heparin (BD, San Diego, CA, USA) and processed immediately after harvest.

\subsection{Isolation of mononuclear cells from the peripheral blood and collection of spleen cells}

Mononuclear cells from the peripheral blood of healthy dogs and dogs with VL were isolated by gradient separation with Histopaque $^{\circledR} 1077$ and 1119 (Sigma, St. Louis, MO, USA) following the manufacturer's recommendations. Then, the isolated cells were washed three times in phosphate buffered saline (PBS) $\mathrm{pH}$ 7.2 and resuspended in RPMI 1640 (Sigma, St. Louis, MO, USA) supplemented as described above and maintained at $37^{\circ} \mathrm{C}$ with $5 \% \mathrm{CO}_{2}$ (Revco, Waltham, MA, USA). The total spleen cells were obtained from a $2 \mathrm{~cm}^{2}$ fragment that was macerated and added to $10 \mathrm{~mL}$ of RPMI-1640 medium supplemented as described above. After removal of cellular "debris" (BD Falcon Cell strainer, San Diego, CA, USA), the suspension was processed with $5 \mathrm{~mL}$ of lysis buffer containing $7.46 \mathrm{~g} / \mathrm{L}$ of ammonium chloride $\left(\mathrm{NH}_{4} \mathrm{ClO}_{3}\right)$ at $4{ }^{\circ} \mathrm{C}$ for $10 \mathrm{~min}$, centrifuged at $2000 \mathrm{rpm}$ for $5 \mathrm{~min}$ and washed three times with phosphate buffered saline, $\mathrm{pH}$ 7.2.

For flow cytometry, the cells were processed immediately after their separation, and the cell cultures were incubated at $37^{\circ} \mathrm{C}$ in a $5 \% \mathrm{CO}_{2}$ incubator for $72 \mathrm{~h}$.

\subsection{Antibodies}

The following FITC-conjugated monoclonal antibodies were used: anti-CD3, canine ( $5 \mu \mathrm{L} / \mathrm{mL}$; Serotec, Kidlington, OX, UK), antiCD21 canine ( $15 \mu \mathrm{L} / \mathrm{mL}$; Exbio, Czech Republic) anti-F4/80 mouse ( $5 \mu \mathrm{L} / \mathrm{mL}$; Abcam, CA, UK) (Diaz et al., 2012) and isotype controls (0.05 mL; BD Biosciences, San Diego, CA, USA). The following monoclonal antibodies conjugated to PE were also used: Anti-human CD279 (PD-1, the PD1 protein shows high degree of homology between the canine and human species (Folkl et al., 2010)), antihuman CD274 (PD-L1), anti-human CD273 (PD-L2) (15 $\mu \mathrm{L} / \mathrm{mL}, \mathrm{BD}$ Biosciences, San Diego, CA, USA) and isotype controls. Finally, monoclonal anti-human CD279 blocking (PD-1), anti-human CD273 (B7-DC) and anti-mouse CD274 (B7-H1), (5 $\mu \mathrm{L} / \mathrm{mL}$, eBioscience, San Diego, CA, USA) were used.

\subsection{Flow cytometry}

For fluorochrome labeling, the cells were suspended in PBS containing $1 \%$ bovine serum albumin, $0.1 \%$ azide and $20 \%$ fetal bovine serum to block the Fc receptors (FCRs). The cells were incubated with monoclonal antibodies for $30 \mathrm{~min}$ at $4{ }^{\circ} \mathrm{C}$, washed twice with PBS containing $2 \%$ fetal bovine serum, then stored at $4{ }^{\circ} \mathrm{C}$ in the dark until flow cytometric acquisition (BD Accuri C5 Flow Cytometer, San Diego, CA, USA) and analysis using BD Accuri C6 software, Version 1.0.264.21 to quantify the expression of PD-1, PD-L1, PD-L2, CD3, CD21 and F4/80. Ten thousand events were acquired, excluding cellular "debris.Ïsotype controls (BD Biosciences, San Diego, CA, USA) were used to delimit the negative populations of cells doubly stained with PE/FITC.

\subsection{Culture of peripheral blood and splenic mononuclear cells from infected dogs with blocking PD-1, PD-L1, PD-L2}

Approximately $5 \times 10^{6}$ mononuclear cells from the peripheral blood and spleens of dogs with VL were suspended in $1 \mathrm{~mL}$ of RPMI 1640 medium (Gibco, Waltham, MA, USA) supplemented as previously described. The cells were grown on 24 -well plates (Costar,
Sigma, St. Louis, MO, USA) in the presence of $5 \mu \mathrm{g} / \mathrm{mL}$ of blocking antibodies to PD-1, PD-L1 or PD-L2 (Dulgerian et al., 2011) or isotype controls. The cultures were incubated at $37^{\circ} \mathrm{C}$ in a $5 \%$ $\mathrm{CO}_{2}$ incubator for $72 \mathrm{~h}$. The cells were used for the assessment of $\mathrm{CD}^{+} \mathrm{T}$ cell apoptosis, and the culture supernatants were centrifuged at $2500 \mathrm{rpm}$ and stored in the freezer at $-80^{\circ} \mathrm{C}$ for TNF- $\alpha$ and IL- 4 measurements or at $-20^{\circ} \mathrm{C}$ for nitric oxide measurements. The percentage of apoptotic $\mathrm{CD}^{+} \mathrm{T}$ lymphocytes was determined using the Guava nexin commercial reagent kit (Millipore, Darmstadt, Germany) following the manufacturer's instructions. Flow cytometric analysis was performed as described above. The cells were considered to be in the final stage of apoptosis when they were positive for 7-AAD and Annexin V-PE.

\subsection{Cytokine assay for TNF- $\alpha$ and IL-4}

TNF- $\alpha$ and IL- 4 were evaluated in the supernatants of mononuclear cell cultures from the peripheral blood and spleen after centrifugation at $2000 \mathrm{rpm}$ for $5 \mathrm{~min}$ using a capture ELISA (R\&D Systems, Minneapolis, USA) according to the manufacturer's instructions. The optical density at $450 \mathrm{~nm}$ was obtained in a 96well plate reader (Spectra Count, Packard Bio Science Company, Meriden, CT, USA).

\subsection{Nitric oxide dosage}

The nitric oxide levels were measured using the Griess method (Dulgerian et al., 2011) in the supernatants of blood and spleen cell cultures. For this measurement, $100 \mu \mathrm{L}$ of culture supernatant was added to $100 \mu \mathrm{L}$ of Griess reagent (one part $0.1 \%$ NEED and one part sulfanilamide $1 \%$ phosphoric acid, $\mathrm{H}_{3} \mathrm{PO}_{4}$ ). After 5 min of incubation at room temperature, the optical density at $540 \mathrm{~nm}$ was obtained using a 96-well plate reader (Spectra Count, Packard Bio Science Company, Meriden, CT, USA). The concentration of nitric oxide was obtained after comparison with the sodium nitrite standard curve, ranging from 3 to $200 \mu \mathrm{M}$.

\subsection{Quantification of parasite load}

Peripheral blood mononuclear cells $\left(5 \times 10^{6}\right)$ from 10 dogs with VL were suspended in RPMI 1640 medium (Gibco, Waltham, MA, USA) supplemented as previously described. The cells were grown in 24-well sterile culture plates (Costar, Sigma, St. Louis, MO, USA) containing sterile, LPS-free glass circular cover slips (15 mm diameter, Perfecta coverslips, Sao Paulo, Brazil) in the presence or absence of $5 \mu \mathrm{g} / \mathrm{mL}$ of blocking monoclonal antibody against PD-1, PD-L1 or PD-L2. After 5 days of incubation at $37^{\circ} \mathrm{C}$ and $5 \% \mathrm{CO}_{2}$, the coverslips were scraped and the cells were subjected to cytospin at $1000 \mathrm{rpm}$ for $5 \mathrm{~min}$ at room temperature. The slides were stained with a commercial hematological dye (Instant-Prov, Newprov, Pinhais, PR, Brazil) to count the parasites within the macrophages. At least 100 cells were counted under light microscopy to determine the macrophage infection rate (Eclipse E800, Nikon, Tokyo, $\mathrm{JP}$ ), differentiating infected cells from those not parasitized, while the parasite load was determined after dividing the number of amastigotes by the number of infected macrophages. TNF- $\alpha$ were also evaluated in the supernatants of mononuclear cell cultures from the peripheral blood using a capture ELISA (R\&D Systems, Minneapolis, USA) according to the manufacturer's instructions as described above.

\subsection{Statistical analysis}

The non-parametric Mann-Whitney test was used to compare the expression of PD-1, PD-L1, and PD-L2 on total lymphocytes, $\mathrm{CD}^{+} \mathrm{T}$ cells, B lymphocytes, $\mathrm{CD} 21^{+}$and $\mathrm{F} 4 / 80^{+}$monocytes, 

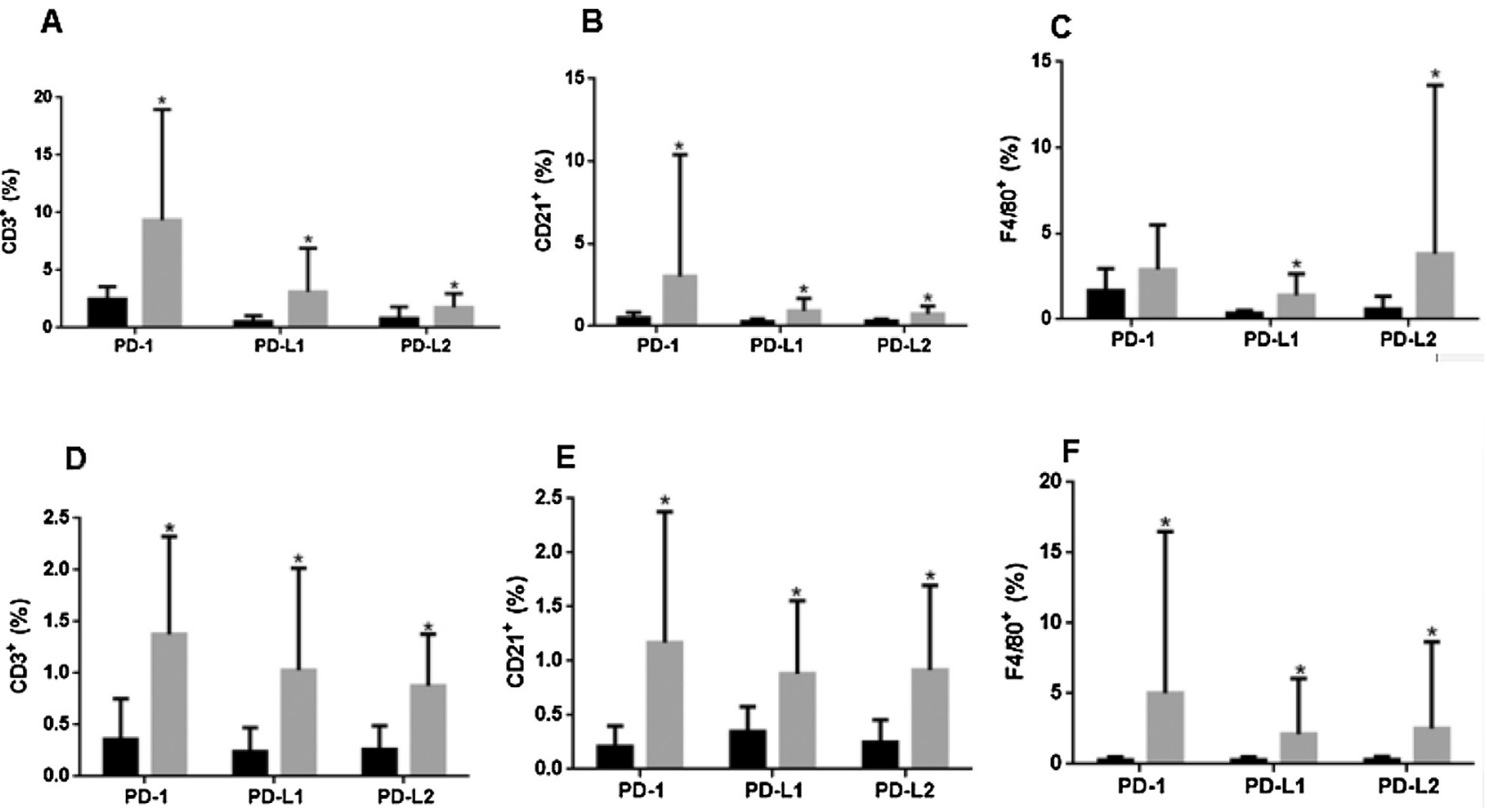

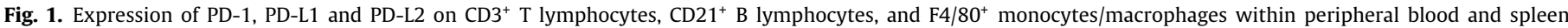

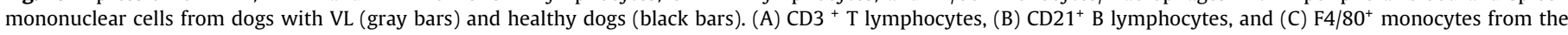

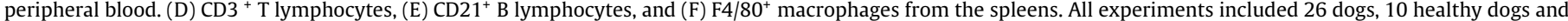
16 dogs with VL. Graphical data presented as the mean and standard deviation; ${ }^{*} \mathrm{p}<0.05$ by Mann Whitney test (A-F).

mononuclear blood cells and leukocytes from the spleen and apoptotic $\mathrm{CD}^{+} \mathrm{T}$ lymphocytes in dogs with VL vs. healthy dogs. The Wilcoxon test and paired t test was used to compare the levels of apoptotic $\mathrm{CD}^{+}{ }^{+} \mathrm{T}$ cells, TNF- $\alpha$ and IL- 4 cytokines and nitric oxide. The parametric paired $t$ test was used for the analysis of the parasite load in blood mononuclear cells from dogs with VL. The statistical analyses were performed and graphed using the computer program GraphPad Prism 6 (GraphPad Software, Inc., CA, USA), and a difference between the means of two groups was considered to be significant at $\mathrm{p}<0.05$.

\section{Results}

\subsection{Evaluation of $P D-1, P D-L 1$ and $P D-L 2$ expression on} mononuclear cells from the peripheral blood and spleens of dogs with VL and healthy dogs

Our aim was to evaluate whether chronic infection of dogs by Leishmania spp. alters the expression of PD-1 and its ligands in $\mathrm{CD}^{+} \mathrm{T}$ lymphocytes, $\mathrm{CD} 21^{+}$B lymphocytes, and $\mathrm{F} 4 / 80^{+}$monocytes/macrophages within mononuclear cells from the peripheral blood and spleen. We observed increased expression of PD-1 and its ligands PD-L1/PD-L2 ( $\mathrm{p}<0.05)$ in $\mathrm{CD}^{+}$T lymphocytes (Fig. 1A) and $\mathrm{CD} 21^{+} \mathrm{B}$ lymphocytes (Fig. 1B) in peripheral blood mononuclear cells from dogs with VL. In $\mathrm{F} 4 / 80^{+}$monocytes, only the expression of the ligands PD-L1 and PD-L2 was significantly increased (Fig. 1C). $\mathrm{CD}^{+} \mathrm{T}$ lymphocytes, $\mathrm{CD} 21^{+}$B lymphocytes and $\mathrm{F} 4 / 80^{+}$ macrophages from the spleens of dogs with VL showed increased expression of PD1, PD-L1 and PD-L2-1 ( $\mathrm{p}<0.05$ ) (Fig. 1D, E and F, respectively).

Fig. 2 contains representations of the detection of doublelabeled $\mathrm{CD}^{+} / \mathrm{PD}-1, \mathrm{CD}^{+} / \mathrm{PD}-\mathrm{L} 1, \mathrm{CD}^{+} / \mathrm{PD}-\mathrm{L} 2 \mathrm{~T}$ lymphocytes within mononuclear cells from the peripheral blood (Fig. 2A, B and C) and spleen (Fig. 2D, E and F).
Table 1

Expression of PD1 and its ligands (mean and standard deviation) in $\mathrm{CD}^{+}, \mathrm{F} 4 / 80^{+}$ and $\mathrm{CD} 21^{+}$mononuclear cells from the peripheral blood of dogs with $\mathrm{VL}$.

\begin{tabular}{llll}
\hline Expression & $\mathrm{CD}^{+}(\%)$ & $\mathrm{F} 4 / 80^{+}(\%)$ & $\mathrm{CD} 21^{+}(\%)$ \\
\hline PD-1 & $9.36 \pm 9.60 \mathrm{a}$ & $2.89 \pm 2.60 \mathrm{~b}$ & $3.02 \pm 7.37 \mathrm{~b}$ \\
PD-L1 & $3.11 \pm 3.82 \mathrm{a}$ & $1.39 \pm 1.25 \mathrm{~b}$ & $0.93 \pm 0.75 \mathrm{~b}$ \\
PD-L2 & $1.79 \pm 1.20 \mathrm{a}$ & $1.35 \pm 1.06 \mathrm{a}$ & $0.73 \pm 0.49 \mathrm{~b}$ \\
\hline
\end{tabular}

a,b Equal letters in the same line indicate no statistical difference, Wilcoxon test $(\mathrm{p}<0.05)$.

Table 2

Expression of PD1 and its ligands (mean and standard deviation) in $\mathrm{CD}^{+}, \mathrm{F} 4 / 80^{+}$ and $\mathrm{CD} 21^{+}$spleen cells from dogs with VL.

\begin{tabular}{llll}
\hline Expression & $\mathrm{CD}^{+}(\%)$ & $\mathrm{F} 4 / 80^{+}(\%)$ & $\mathrm{CD} 21^{+}(\%)$ \\
\hline PD-1 & $1.37 \pm 0.94 \mathrm{a}$ & $1.53 \pm 2.06 \mathrm{a}$ & $0.90 \pm 0.56 \mathrm{~b}$ \\
PD-L1 & $1.02 \pm 0.99 \mathrm{a}$ & $0.88 \pm 0.88 \mathrm{a}$ & $0.73 \pm 0.35 \mathrm{a}$ \\
PD-L2 & $0.87 \pm 0.50 \mathrm{a}$ & $0.98 \pm 0.96 \mathrm{a}$ & $0.91 \pm 0.77 \mathrm{a}$
\end{tabular}

a,b Equal letters in the same line indicate no statistical difference, Wilcoxon test $(\mathrm{p}<0.05)$.

Next, the expression of PD1 and its binding was evaluated in cells from dogs with VL. The results indicated that $\mathrm{CD}^{+} \mathrm{T}$ lymphocytes exhibited the highest cell expression of PD- 1 and its ligands compared to $\mathrm{F} 4 / 80^{+}$monocytes and $\mathrm{CD} 21^{+} \mathrm{B}$ lymphocytes within peripheral blood mononuclear cells, except for PD-L2 in F4/80 cells (Table 1 ). In the spleen, $\mathrm{CD}^{+} \mathrm{T}$ lymphocytes had increased expression of PD- 1 only compared to CD $21^{+}$B cells (Table 2 ).

\subsection{Quantification of apoptosis in $\mathrm{CD}^{+}$T lymphocytes from the peripheral blood and spleens of dogs with $V L$ in the presence of blocking monoclonal antibodies to PD-1, PD-L1 and PD-L2}

Due to the increased expression of PD-1 and its ligands PD-L1/PD-L2 during infection by Leishmania spp. in dogs, we attempted to investigate its role in cellular apoptosis. High rates of 
PBMC
Splenic cells

Health
Infected

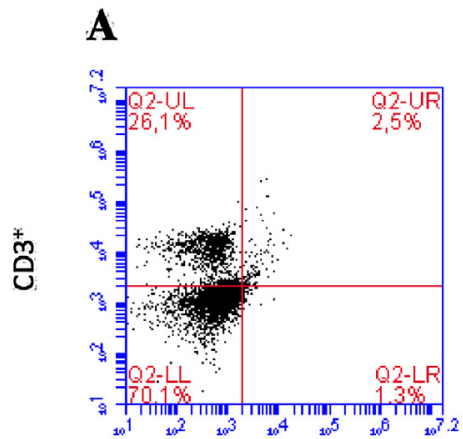

PD-1
D

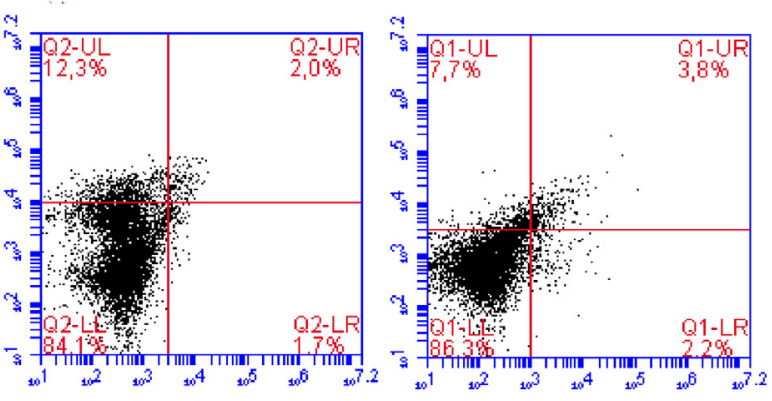

P.D-1

B

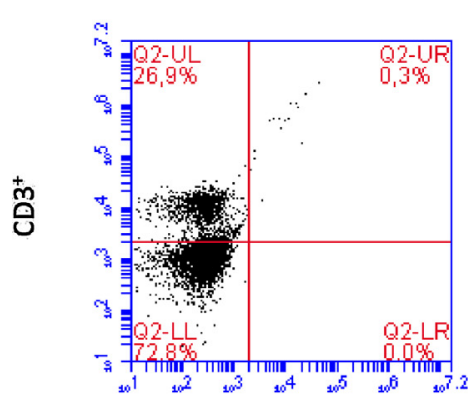

PD-L1

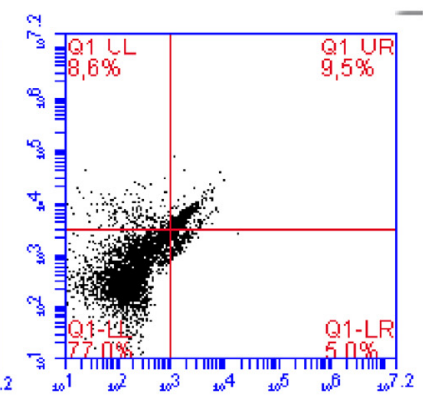

$\mathbf{E}$

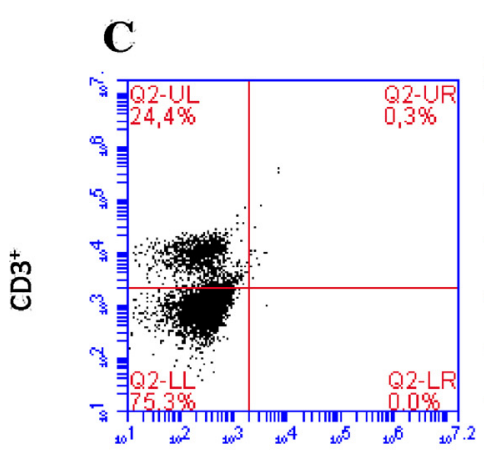

PD-L2

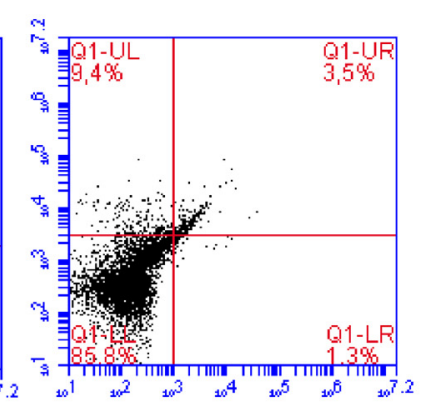

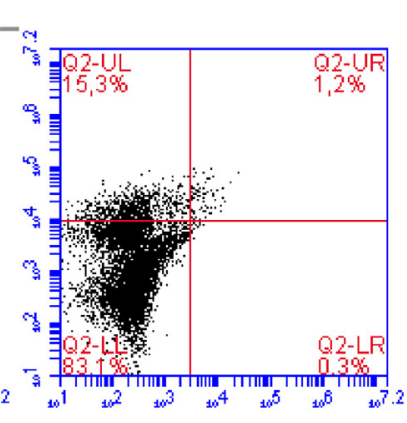

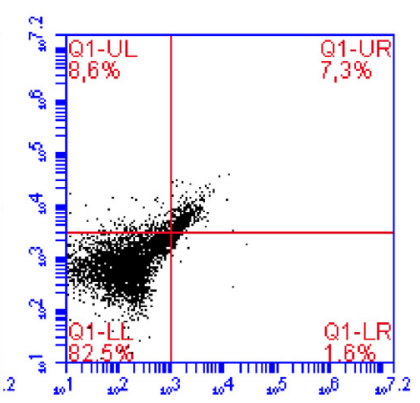

PD-L1
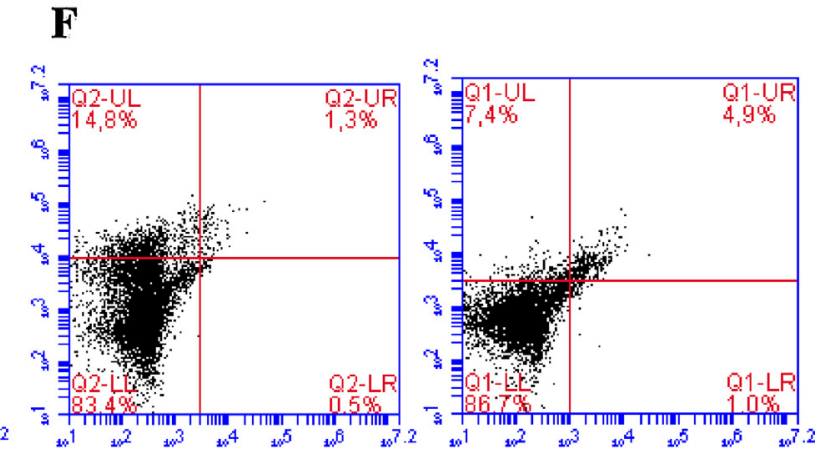

PD-L2

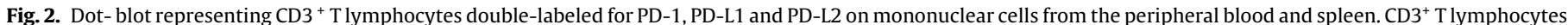

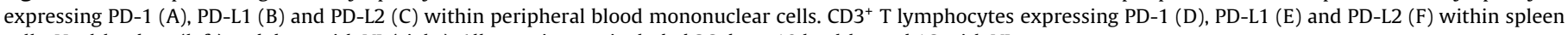
cells. Healthy dogs (left) and dogs with VL (right). All experiments included 26 dogs, 10 healthy and 16 with VL.

apoptosis of $\mathrm{CD}^{+} \mathrm{T}$ lymphocytes in the spleens and peripheral blood of infected dogs has been described (Lima et al., 2012). Thus, we evaluated whether the apoptosis of $\mathrm{CD}^{+} \mathrm{T}$ lymphocytes observed in the infected dogs required $\mathrm{PD}-1$ receptors and their ligands. The data confirmed that $\mathrm{CD}^{+} \mathrm{T}$ lymphocytes from the peripheral blood and spleens in dogs with VL had higher levels of apoptosis compared to those from healthy dogs $(p<0.05)$ (Fig. 3A, B). The use of blocking monoclonal antibodies to PD1 and its ligands in peripheral blood mononuclear cell and spleen cell cultures decreased the apoptosis rate of $\mathrm{CD}^{+}$T lymphocytes $(\mathrm{p}<0.05)$ (Fig. 3C and D).
3.3. Determination of the nitric oxide concentration and TNF- $\alpha$ and IL-4 levels in the culture supernatants of mononuclear cells from the peripheral blood and spleens of dogs with VL after blockade of $P D-1$ receptors and its ligands

We investigated whether PD1 and its ligands have a regulatory effect on other cellular functions such as the production of nitric oxide and the cytokines TNF- $\alpha$ and IL- 4 in the culture supernatants of mononuclear cells from the peripheral blood and spleen.

The concentrations of nitric oxide (Fig. 4A), TNF- $\alpha$ (Fig. 4B) and IL-4 (Fig. 4D) increased in the culture supernatants of mononuclear 
A

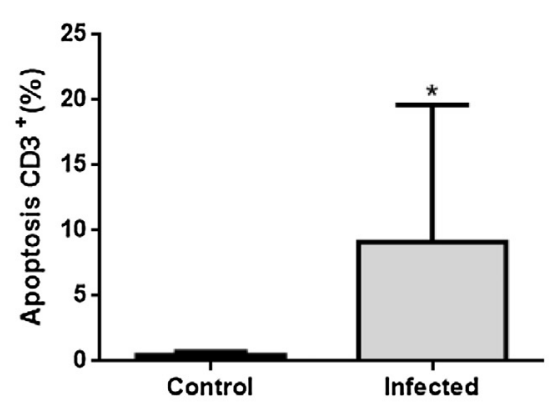

C

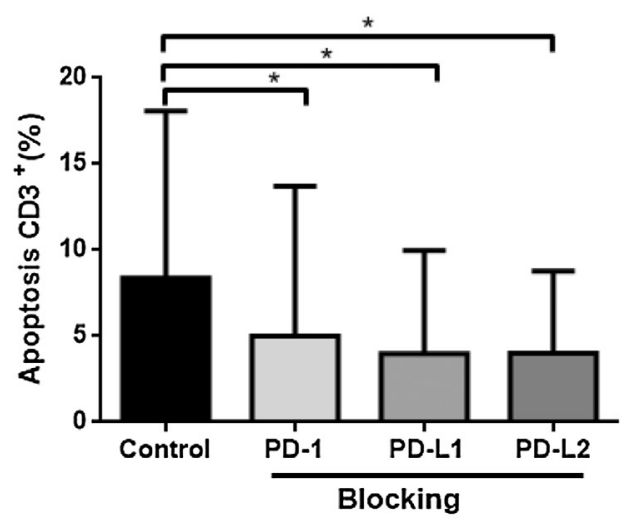

B

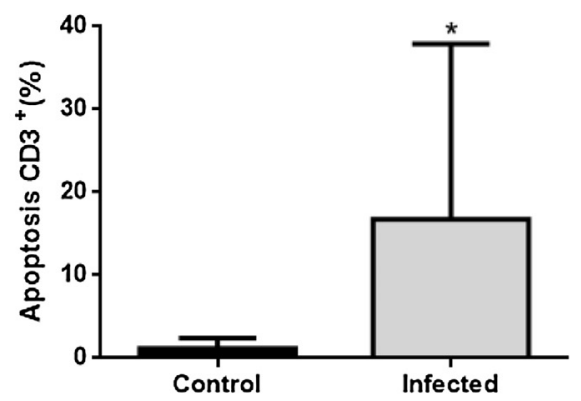

D

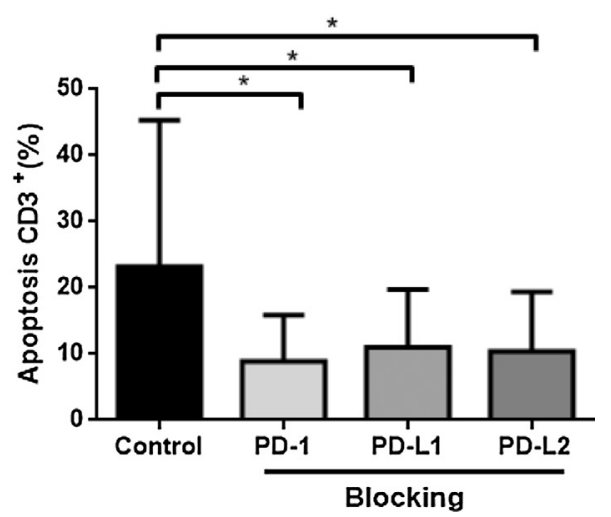

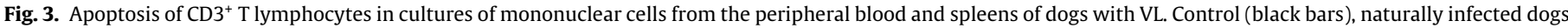

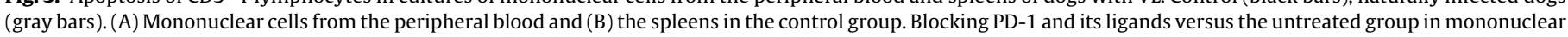

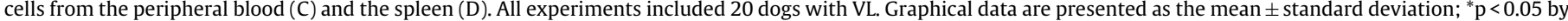
Unpaired t test (A); Mann Whitney test (B) or Wilcoxon test (C, D).

cells from the peripheral blood treated with PD-1 blocking monoclonal antibody compared to untreated cell cultures $(\mathrm{p}<0.05)$.

In splenic cells, an increase in the TNF- $\alpha$ concentration was observed following treatment with antibodies blocking PD-1 and its ligands ( $p<0.05$ ) (Fig. 4C). An increase in IL-4 was observed only after blocking PD-1 (Fig. 4E).

\subsection{Parasitic load in cultures of peripheral blood mononuclear cells of dogs with VL in the presence of blocking monoclonal antibodies to $P D-1$ and its ligands}

We next investigated whether PD1 and its ligands can modulate the parasitic load of dogs with VL using peripheral blood mononuclear cells treated with blocking monoclonal antibodies, also supernatants of these cultures were used to measure TNF- $\alpha$ production. Treatment with a PD-1 blocking monoclonal antibody reduced the parasite burden $(\mathrm{p}<0.05)$ (Fig. 5A) and an increase in the TNF- $\alpha$ concentration ( $p<0.05$ ) (Fig. 5B) compared to the untreated cells.

\section{Discussion}

Our results demonstrate the increased expression of PD1 and its ligands in $\mathrm{CD}^{+} \mathrm{T}$ lymphocytes, F4/80 cells and $\mathrm{CD} 21^{+} \mathrm{B}$ lymphocytes in the spleens and peripheral blood of dogs with VL. These molecules are related with the induction of apoptosis of $\mathrm{CD}^{+} \mathrm{T}$ lymphocytes because blockade of PD-1 and its ligands in cultures of splenic cells and PBMCs was able to modulate the apoptosis of
$\mathrm{CD}^{+} \mathrm{T}$ lymphocytes, alter the production of TNF- $\alpha$, IL-4 and nitric oxide, and reduce the parasitic load.

The high expression of PD-1 in T lymphocytes observed in our study in the peripheral blood and spleens is similar to that observed for (Esch et al., 2013), where $\mathrm{CD} 4^{+} \mathrm{CD}^{+}$peripheral blood cells from dogs with symptomatic and asymptomatic VL presented increased PD-1 expression. In dogs with $\mathrm{VL}, \mathrm{CD}^{+} \mathrm{T}$ lymphocytes in the peripheral blood have increased expression of PD-1 and its ligands compared to $\mathrm{F} 4 / 80^{+}$monocytes and $\mathrm{CD} 21^{+}$B lymphocytes; however, in the spleen, only PD-1 expression was increased in $\mathrm{CD}^{+} \mathrm{T}$ lymphocytes compared to $\mathrm{CD} 21^{+} \mathrm{B}$ lymphocytes.

This report is the first describing PD-1, PD-L1 and PD-L2 expression in $\mathrm{CD}^{+} \mathrm{T}$ lymphocytes, $\mathrm{CD} 21^{+} \mathrm{B}$ lymphocytes and $\mathrm{F} 4 / 80^{+}$cells in healthy dogs and dogs with VL. Although there are no reports in dogs, the expression of these molecules has also been characterized in other experimental models of chronic diseases, such as HIV (D'Souza et al., 2007) and tuberculosis (McNab et al., 2011).

In agreement with previously reported results (Lima et al., 2012; Perosso et al., 2014; Silva et al., 2013), we observed an increase in the apoptosis of $\mathrm{CD}^{+} \mathrm{T}$ lymphocytes from the peripheral blood and spleens of dogs with VL. This suggests that apoptosis may be involved in the low lymphoproliferative response during this disease, as previously reported by (Esch et al., 2013), and therefore may contribute to the failure of immunity, the emergence of coinfection and the development of neoplasms that are observed in dogs chronically infected by Leishmania spp. (Foglia Manzillo et al., 2008; Oliveira et al., 2008).

The use of blocking monoclonal antibodies against PD1 and its ligands in cultured mononuclear cells from the peripheral blood 
A

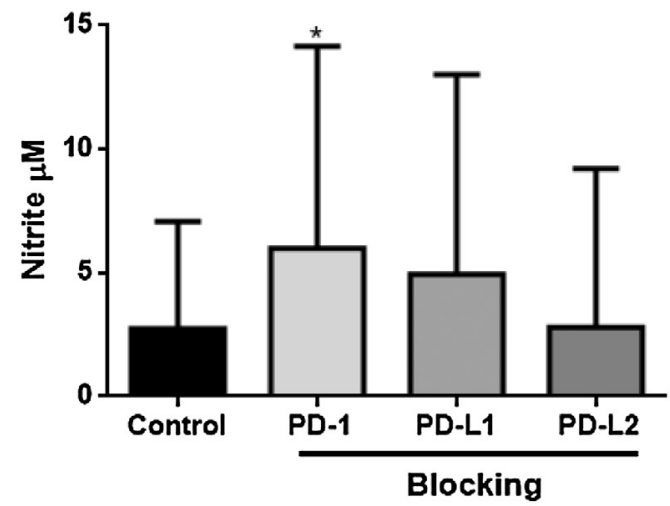

B

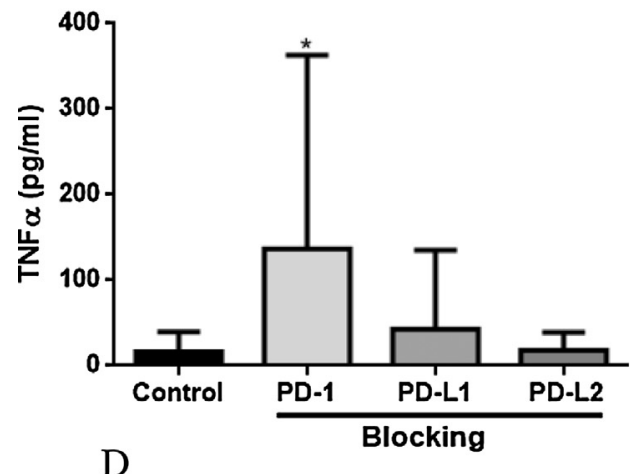

$\mathrm{D}$

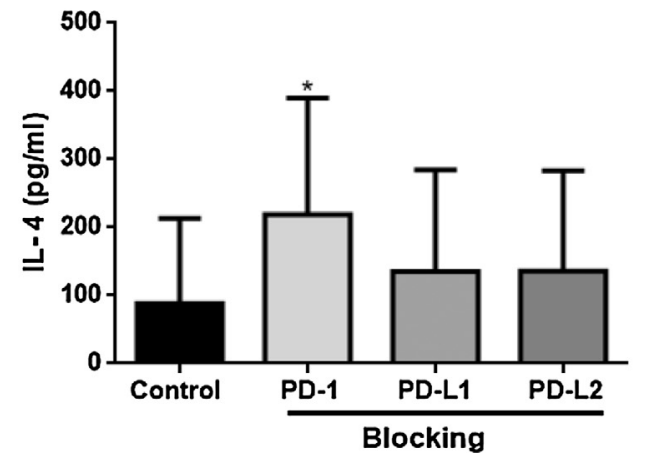

$\mathrm{C}$

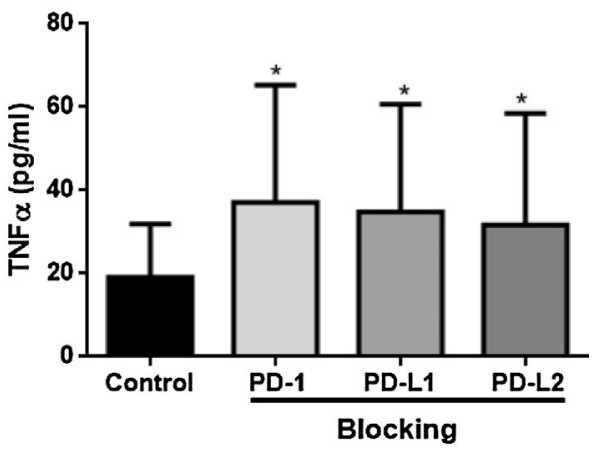

$\mathrm{E}$

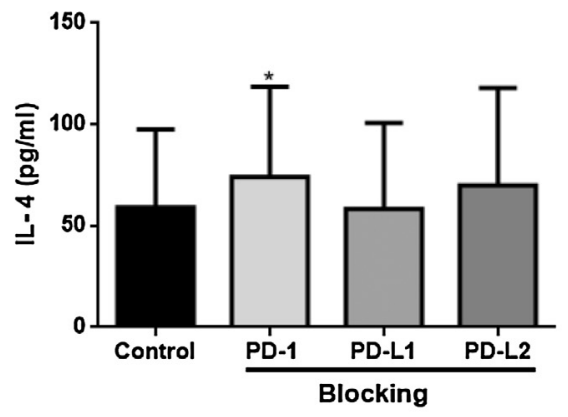

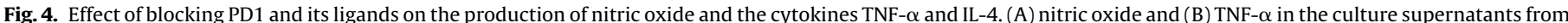

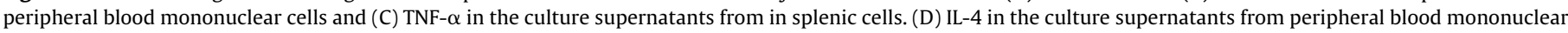

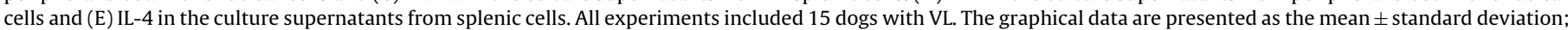
* $\mathrm{p}<0.05$ by Wilcoxon test (A,B,D); paired t test (C-E).

and spleen led to decreased apoptosis in $\mathrm{CD}^{+} \mathrm{T}$ lymphocytes, suggesting that these receptors participate in the apoptotic process. Inhibition of T lymphocyte apoptosis is not complete because it is still detected, suggesting that other inducers of cell death pathways are still active. In fact, other receptors, including transmembrane Fas/FasL (Silva et al., 2013) and soluble Fas/FasL (Perosso et al., 2014) have been shown to be involved in the apoptosis of T lymphocytes $\left(\mathrm{CD}^{+}, \mathrm{CD}^{+}\right.$and $\left.\mathrm{CD}^{+}\right)$in dogs with VL.

Inhibition of $\mathrm{CD}^{+} \mathrm{T}$ lymphocyte apoptosis in dogs with VL using blocking antibodies against PD-1 and its ligands in vitro suggests that the therapeutic use of monoclonal antibodies in dogs with VL may help to increase T lymphocyte numbers in the peripheral blood and spleens and reestablish their immune function.

In our experiments, blocking monoclonal antibodies were used in culture to block PD-1 and its ligands present on T lymphocytes and macrophages, thereby inhibiting apoptosis by this pathway. As both PD1 and PD-L1 are expressed on T lymphocytes, B lymphocytes and macrophages, there is the possibility for a two-way interaction between PD-1 and PD-L1 (Sharpe et al., 2007). Unlike our results, (Esch et al., 2013) used blocking antibodies only in 
A

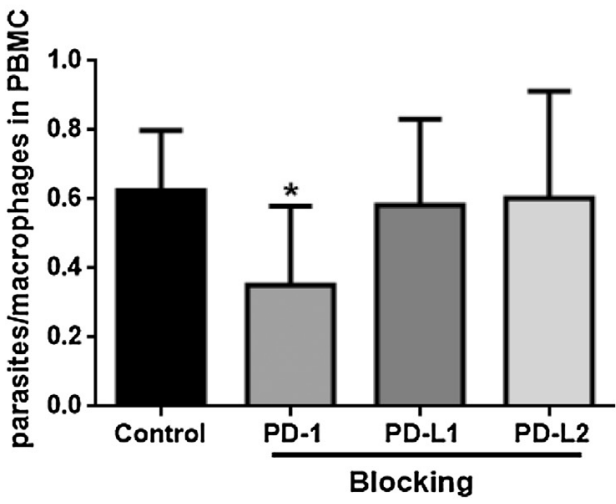

B

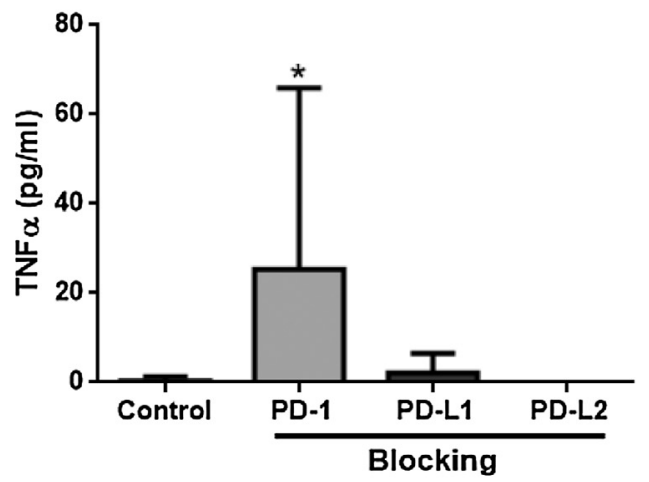

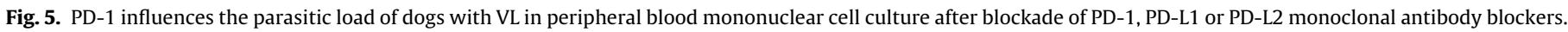

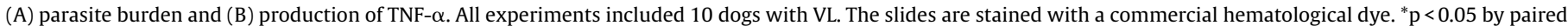
t-test (A) and Wilcoxon test (B).

adherent cells and found that the PD- 1 receptor is not involved in cell apoptosis in dogs with VL; this difference is likely due to diferences in experimental design. Our data suggest that the PD1 receptor and its ligands are involved in the induction of $\mathrm{CD}^{+} \mathrm{T}$ lymphocyte apoptosis.

An increase in the amount of nitric oxide was observed in the presence of blocking monoclonal antibodies to PD-1 in cultures of mononuclear cells from the peripheral blood of dogs with VL. Nitric oxide production in canine macrophages is correlated with the induction of anti-leishmania activity (Pinelli et al., 2000). Similar to our studies, in other models such as in macrophages of mice infected with $T$. cruzi, it was also observed that PD-1 and PD-L1 blockade increased iNOS expression and nitric oxide production (Dulgerian et al., 2011). Our results indicate that PD1 interferes with nitric oxide production in mononuclear cells from the peripheral blood of dogs with VL, as blockade of this receptor increased nitric oxide production.

TNF- $\alpha$ is present in a higher concentration in cultures of peripheral blood mononuclear cells treated with PD-1 blocking monoclonal antibodies compared to untreated cultures. In the spleen culture supernatants, all treatments carried out resulted in an increase in the TNF- $\alpha$ concentration. It is possible that the blocking antibodies inhibited the interaction of PD- 1 and its ligands, as the ligation of PD-1 by PD-L1 or PD-L2 has been shown to inhibit the signal transduction triggered by TCR/CD3, blocking downstream $\mathrm{T}$ lymphocyte proliferation and cytokine production (Freeman et al., 2000; Latchman et al., 2001).

The increase in TNF- $\alpha$ concentration observed after blocking PD1 and its ligands may be related to increased microbicidal activity because the resistance of the intracellular survival of $L$. infantum in canine macrophages is mainly associated with the increased production of this cytokine (Turchetti et al., 2015). It was also reported that TNF- $\alpha$ enhances nitric oxide production in canine macrophages (Pinelli et al., 2000). Although there are no reports in dogs, in a sepsis model in mice, PD-L1 blockade also increased the TNF- $\alpha$ levels and decreased the bacterial load in the blood and peritoneal fluid (Zhang et al., 2010). Indeed, TNF- $\alpha$ expression is regulated by signaling via PD- 1 (Wei et al., 2013). Thus, the TNF- $\alpha$ production observed in our studies may influence the nitric oxide production and reduce the parasite load.

In our study there was an increase in IL- 4 only in the presence of a PD-1 blocking monoclonal antibody in cultures of mononuclear cells from both the peripheral blood and the spleen. The role of IL- 4 in the polarization of the immune response towards Th2 in dogs with VL is controversial. Dogs experimentally infected with L. infantum with low parasite burden in their peripheral blood mononuclear cells do not express IL-4, but its expression increases with the appearance of clinical signs of VL (Sanchez-Robert et al., 2008). However, no differences between IL-4 levels can be observed between symptomatic and asymptomatic dogs (Leal et al., 2014). The IL-4 production in our study appears to have a protective role because it was associated with a lower parasite load and with the increased production of nitric oxide and TNF- $\alpha$.

The protective effect of IL- 4 has been previously observed in experimental VL. The elevated production of IL-4 and concomitant production of nitric oxide were associated with protection in hamsters after vaccination with VL (Basu et al., 2005). Knockout mice for IL- 4 were most susceptible to infection by Leishmania donovani, also suggesting a protective ability of IL-4 against VL (Satoskar et al., 1995). In mice, IL-4 expression was essential and necessary for Th1 differentiation and the maintenance of IFN- $\gamma$ production (Kamogawa et al., 1993). IL-4 expression in a mouse model is not easily regulated by the inhibitory effect of PD-1 (Latchman et al., 2001); however, in dogs with VL, we noted that PD-1 blockade improved IL-4 production.

Treatment with a PD-1 blocking monoclonal antibody in mononuclear cells from the peripheral blood of dogs with VL decreased the parasite burden, similar to that observed for Esch et al. (2013). In mice infected with $L$. donovani and treated with a PD-L1 blocker, a reduction of parasite multiplication in the spleen was observed (Joshi et al., 2009). Our results suggest that the PD-1 receptor can modulate the parasitic load of dogs with VL.

In an effort to evaluate the possible mechanism that reduced the parasite burden, TNF- $\alpha$ production were measured. We observed blocking PD-1 decreased parasite load and increased TNF- $\alpha$ concentration. Study showed that increased production of TNF- $\alpha$ with decreased intracelular survival of $L$. infantum in canine macrophages (Turchetti et al., 2015). Our findings suggesting that PD- 1 blocking promotes TNF- $\alpha$ production and contribute to control of parasite multiplication. In fact, high levels of TNF- $\alpha$ was related to the control of parasitic growth in spleen samples of dogs naturally infected by L. infantum (Cavalcanti et al., 2015; Nascimento et al., 2013). In this context, general reduction of parasite load could be related with increase of TNF- $\alpha$ production induced by PD1 blocking in dogs with VL.

We conclude that PD-1 and its ligands participate in the induction of $\mathrm{T}$ lymphocyte apoptosis and are capable of regulating nitric oxide, TNF- $\alpha$, and IL- 4 production, as well as reducing the parasitic load. Therefore, our results have implications for better understanding the mechanisms that modulate apoptosis as well as 
immunotherapeutic drugs, such as blocking monoclonal antibodies that can influence CVL.

\section{Conflict of interest}

None.

\section{Acknowledgments}

The authors would like to thank the FAPESP for the financial support of this research (process no. 2013/06684-9) and the granting of masters scholarship (process no. 2013/19399-0) and CAPES.

\section{References}

Alvar, J., Vélez, I.D., Bern, C., Herrero, M., Desjeux, P., Cano, J., Jannin, J., den Boer, M., Team, W.L.C., 2012. Leishmaniasis worldwide and global estimates of its incidence. PLoS One 7, e35671.

Basu, R., Bhaumik, S., Basu, J.M., Naskar, K., De, T., Roy, S., 2005. Kinetoplastid membrane protein-11 DNA vaccination induces complete protection against both pentavalent antimonial-sensitive and -resistant strains of Leishmania donovani that correlates with inducible nitric oxide synthase activity and IL-4 generation: evidence for mixed Th1- and Th2-like responses in visceral leishmaniasis. J. Immunol. 174, 7160-7171.

Bourdoiseau, G., Bonnefont, C., Magnol, J.P., Saint-André, I., Chabanne, L., 1997. Lymphocyte subset abnormalities in canine leishmaniasis. Vet. Immunol. Immunopathol. 56, 345-351.

Cabral, M., O'Grady, J., Alexander, J., 1992. Demonstration of Leishmania specific cell mediated and humoral immunity in asymptomatic dogs. Parasite Immunol. 14, 531-539.

Cavalcanti, A.S., Ribeiro-Alves, M., Pereira, L.e.O., Mestre, G.L., Ferreira, A.B., Morgado, F.N., Boité, M.C., Cupolillo, E., Moraes, M.O., Porrozzi, R., 2015. Parasite load induces progressive spleen architecture breakage and impairs cytokine mRNA expression in Leishmania infantum-naturally infected dogs. PLoS One 10, e0123009.

Coura-Vital, W., Marques, M.J., Veloso, V.M., Roatt, B.M., Aguiar-Soares, R.D., Reis, L.E., Braga, S.L., Morais, M.H., Reis, A.B., Carneiro, M., 2011. Prevalence and factors associated with Leishmania infantum infection of dogs from an urban area of Brazil as identified by molecular methods. PLoS Negl. Trop. Dis. 5, e1291.

D’Souza, M., Fontenot, A.P., Mack, D.G., Lozupone, C., Dillon, S., Meditz, A., Wilson, C.C., Connick, E., Palmer, B.E., 2007. Programmed death 1 expression on HIV-specific CD4+ T cells is driven by viral replication and associated with $\mathrm{T}$ cell dysfunction. J. Immunol. 179, 1979-1987.

Day, C.L., Kaufmann, D.E., Kiepiela, P., Brown, J.A., Moodley, E.S., Reddy, S., Mackey, E.W., Miller, J.D., Leslie, A.J., Depierres, C., Mncube, Z., Duraiswamy, J., Zhu, B., Eichbaum, Q., Altfeld, M., Wherry, E.J., Coovadia, H.M., Goulder, P.J., Klenerman, P., Ahmed, R., Freeman, G.J., Walker, B.D., 2006. PD-1 expression on HIV specific T cells is associated with T-cell exhaustion and disease progression. Nature 21, 350-354.

Diaz, S., da Fonseca, I.P., Rodrigues, A., Martins, C., Cartaxeiro, C., Silva, M.J., de Brito, T.V., Alexandre-Pires, G., Santos-Gomes, G.M., 2012. Canine leishmaniosis. Modulation of macrophage/lymphocyte interactions by $L$ infantum. Vet. Parasitol. 189, 137-144.

Dong, H., Strome, S.E., Salomao, D.R., Tamura, H., Hirano, F., Flies, D.B., Roche, P.C., Lu, J., Zhu, G., Tamada, K., Lennon, V.A., Celis, E., Chen, L., 2002.

Tumor-associated B7-H1 promotes T-cell apoptosis: a potential mechanism of immune evasion. Nat. Med. 8, 793-800

Dos-Santos, W.L., Jesus, E.E., Paranhos-Silva, M., Pereira, A.M., Santos, J.C., Baleeiro, C.O., Nascimento, E.G., Moreira, E.D., Oliveira, G.G., Pontes-de-Carvalho, L.C. 2008. Associations among immunological, parasitological and clinical parameters in canine visceral leishmaniasis: emaciation, spleen parasitism, specific antibodies and leishmanin skin test reaction. Vet. Immunol. Immunopathol. 123, 251-259.

Dulgerian, L.R., Garrido, V.V., Stempin, C.C., Cerbán, F.M., 2011. Programmed death ligand 2 regulates arginase induction and modifies Trypanossoma cruzi survival in macrophages during murine experimental infection. Immunology 133, $29-40$.

Esch, K.J., Juelsgaard, R., Martinez, P.A., Jones, D.E., Petersen, C.A., 2013. Programmed death 1 -mediated $\mathrm{T}$ cell exhaustion during visceral leishmaniasis impairs phagocyte function. J. Immunol. 191, 5542-5550.

Foglia Manzillo, V., Pagano, A., Guglielmino, R., Gradoni, L., Restucci, B., Oliva, G., 2008. Extranodal gamma delta-T-cell lymphoma in a dog with leishmaniasis. Vet. Clin. Pathol. 37, 298-301.

Folkl, A., Wen, X., Kuczynski, E., Clark, M.E., Bienzle, D., 2010. Feline programmed death and its ligand: characterization and changes with feline immunodeficiency virus infection. Vet. Immunol. Immunopathol. 134, $107-114$.

Freeman, G.J., Long, A.J., Iwai, Y., Bourque, K., Chernova, T., Nishimura, H., Fitz, L.J., Malenkovich, N., Okazaki, T., Byrne, M.C., Horton, H.F., Fouser, L., Carter, L. Ling, V., Bowman, M.R., Carreno, B.M., Collins, M., Wood, C.R., Honjo, T., 2000.
Engagement of the PD-1 immunoinhibitory receptor by a novel B7 family member leads to negative regulation of lymphocyte activation. J. Exp. Med. 192, 1027-1034.

Greenwald, R.J., Freeman, G.J., Sharpe, A.H., 2005. The B7 family revisited. Annu. Rev. Immunol. 23, 515-548.

Joshi, T., Rodriguez, S., Perovic, V., Cockburn, I.A., Stäger, S., 2009. B7-H1 blockade increases survival of dysfunctional CD8(+) T cells and confers protection against Leishmania donovani infections. PLoS Pathog. 5, e1000431.

Kamogawa, Y., Minasi, L.A., Carding, S.R., Bottomly, K., Flavell, R.A., 1993. The relationship of IL-4- and IFN gamma-producing T cells studied by lineage ablation of IL-4-producing cells. Cell 75, 985-995.

Lázár-Molnár, E., Yan, Q., Cao, E., Ramagopal, U., Nathenson, S.G., Almo, S.C., 2008. Crystal structure of the complex between programmed death-1 (PD-1) and its ligand PD-L2. Proc. Natl. Acad. Sci. U. S. A. 105, p10483-10488.

Latchman, Y., Wood, C.R., Chernova, T., Chaudhary, D., Borde, M., Chernova, I., Iwai, Y., Long, A.J., Brown, J.A., Nunes, R., Greenfield, E.A., Bourque, K., Boussiotis, V.A., Carter, L.L., Carreno, B.M., Malenkovich, N., Nishimura, H., Okazaki, T., Honjo, T., Sharpe, A.H., Freeman, G.J., 2001. PD-L2 is a second ligand for PD-1 and inhibits T cell activation. Nat. Immunol. 2, 261-268.

Leal, G.G.A., Roatt, B.M., Aguiar-Soares, R.D.O., Carneiro, C.M., Giunchetti, R.C. Carvalho, A.T., Filho, O.A.M., Francisco, A.F., Cardoso, J.M., Mathias, F.A.S., Oliveira, R.C., Caeneiro, M., Vital, W.C., Reis, A.B., 2014. Immunological profile of resistance and susceptibility innaturally infected dogs by Leishmania infantum. Vet. Parasitol. 205, 472-482.

Lima, V.M., Gonçalves, M.E., Ikeda, F.A., Luvizotto, M.C., Feitosa, M.M., 2003. Anti-leishmania antibodies in cerebrospinal fluid from dogs with visceral leishmaniasis. Braz. J. Med. Biol. Res. 36, 485-489.

Lima, V.M., Fattori, K.R., de Souza, F., Eugênio, F.R., dos Santos, P.S., Rozza, D.B., Machado, G.F., 2012. Apoptosis in T lymphocytes from spleen tissue and peripheral blood of L. (L.) chagasi naturally infected dogs. Vet. Parasitol. 184, 147-153.

Loke, P.N., Allison, J.P., 2003. PD-L1 and PD-L2 are differentially regulated by Th1 and Th2 cells. Proc. Natl. Acad. Sci. U. S. A. 100, p5336-5341.

McNab, F.W., Berry, M.P., Graham, C.M., Bloch, S.A., Oni, T., Wilkinson, K.A., Wilkinson, R.J., Kon, O.M., Banchereau, J., Chaussabel, D., O'Garra, A., 2011. Programmed death ligand 1 is over-expressed by neutrophils in the blood of patients with active tuberculosis. Eur. J. Immunol. 41, 1941-1947.

Muhlbauer, M., Fleck, M., Schütz, C., Weiss, T., Froh, M., Blank, C., Schölmerich, J., Hellerbrand, C., 2006. PDL1 is induced in hepatocytes by viral infection and by interferon-alpha and -gamma and mediates T cell apoptosis. J. Hepatol. 45, 520-528.

Nascimento, P.R., Martins, D.R., Monteiro, G.R., Queiroz, P.V., Freire-Neto, F.P. Queiroz, J.W., Morais Lima, A.L., Jeronimo, S.M., 2013. Association of pro-inflammatory cytokines and iron regulatory protein 2 (IRP2) with Leishmania burden in canine visceral leishmaniasis. PLoS One 8, e73873.

Nunes, C.M., Pires, M.M., da Silva, K.M., Assis, F.D., Gonçalves Filho, J., Perri, S.H. 2010. Relationship between dog culling and incidence of human visceral leishmaniasis in an endemic area. Vet. Parasitol. 170, 131-133.

Oliveira, T.M., Furuta, P.I., de Carvalho, D., Machado, R.Z., 2008. A study of cross-reactivity in serum samples from dogs positive for Leishmania sp. Babesia canis and Ehrlichia canis in enzyme-linked immunosorbent assay and indirect fluorescent antibody test. Rev Bras. Parasitol. Vet. 17, 7-11.

Pardoll, D.M., 2012. The blockade of immune checkpoints in cancer immunotherapy. Nat. Rev. Cancer 12, 252-264.

Pentcheva-Hoang, T., Chen, L., Pardoll, D.M., Allison, J.P., 2007. Programmed death-1 concentration at the immunological synapse is determined by ligand affinity and availability. Proc. Natl. Acad. Sci. U. S. A. 104, 17765-17770.

Perosso, J., Silva, K.L., Ferreira, S.I., Avanço, S.V., dos Santos, P.S., Eugênio, F.R., de Almeida, B.F., de Lima, V.M., 2014. Alteration of sFAS and sFAS ligand expression during canine visceral leishmaniosis. Vet. Parasitol. 205, 417-423.

Pinelli, E., Rutten, V.P., Bruysters, M., Moore, P.F., Ruitenberg, E.J., 1999. Compensation for decreased expression of B7 molecules on Leishmania infantum-infected canine macrophages results in restoration of parasite-specific T-cell proliferation and gamma interferon production. Infect. Immun. 67, 237-243.

Pinelli, E., Gebhard, D., Mommaas, A.M., van Hoeij, M., Langermans, J.A., Ruitenberg, E.J., Rutten, V.P., 2000. Infection of a canine macrophage cell line with Leishmania infantum: determination of nitric oxide production and anti-leishmanial activity. Vet. Parasitol. 92, 181-189.

Sanchez-Robert, E., Altet, L., Alberola, J., Rodriguez-Cortés, A., Ojeda, A., López-Fuertes, L., Timon, M., Sanchez, A., Francino, O., 2008. Longitudinal analysis of cytokine gene expression and parasite load in PBMC in Leishmania infantum experimentally infected dogs. Vet. Immunol. Immunopathol. 125, $168-175$.

Santana, C.C., Vassallo, J., de Freitas, L.A., Oliveira, G.G., Pontes-de-Carvalho, L.C., dos-Santos, W.L., 2008. Inflammation and structural changes of splenic lymphoid tissue in visceral leishmaniasis: a study on naturally infected dogs. Parasite Immunol. 30, 515-524.

Satoskar, A., Bluethmann, H., Alexander, J., 1995. Disruption of the murine interleukin-4 gene inhibits disease progression during Leishmania mexicana infection but does not increase control of Leishmania donovani infection. Infect. Immun. 63, 4894-4899.

Sharpe, A.H., Wherry, E.J., Ahmed, R., Freeman, G.J., 2007. The function of programmed cell death 1 and its ligands in regulating autoimmunity and infection. Nat. Immunol. 8, 239-245. 
Silva, J.S., Vespa, G.N., Cardoso, M.A., Aliberti, J.C., Cunha, F.Q., 1995. Tumor necrosis fator alpha mediates resistance to Trypanosoma cruzi infection in mice by inducing nitric oxide production in infected gamma interferon-activated macrophages. Infect. Immun. 63, 4862-4867.

Silva, K.L., Melo, L.M., Perosso, J., Oliveira, B.B., Santos, P.S., Eugênio F. e.R. Lima, V.M., 2013. CD95 (FAS) and CD178 (FASL) induce the apoptosis of CD4+ and CD8+ cells isolated from the peripheral blood and spleen of dogs naturally infected with Leishmania spp. Vet. Parasitol. 197, 470-476.

Solano-Gallego, L., Koutinas, A., Miró, G., Cardoso, L., Pennisi, M.G., Ferrer, L., Bourdeau, P., Oliva, G., Baneth, G., 2009. Directions for the diagnosis, clinical staging, treatment and prevention of canine leishmaniosis. Vet. Parasitol. 165, $1-18$.

Trautmann, L., Janbazian, L., Chomont, N., Said, E.A., Gimmig, S., Bessette, B. Boulassel, M.R., Delwart, E., Sepulveda, H., Balderas, R.S., Routy, J.P., Haddad, E.K., Sekaly, R.P., 2006. Upregulation of PD-1 expression on HIV-specific CD8+ T cells leads to reversible immune dysfunction. Nat. Med. 12, 1198-1202.

Turchetti, A.P., Costa, L.F., Romão, E.L., Fujiwara, R.T., Paixão, T.A., Santos, R.L., 2015. Transcription of innate immunity genes and cytokine secretion by canine macrophages resistant or susceptible to intracellular survival of Leishmania infantum. Vet. Immunol. Immunopathol. 163, 67-76.
Verçosa, B.L., Melo, M.N., Puerto, H.L., Mendonça, I.L., Vasconcelos, A.C., 2012 Apoptosis, inflammatory response and parasite load in skin of Leishmania (Leishmania) chagasi naturally infected dogs: a histomorphometric analysis. Vet. Parasitol. 189, 162-170.

WHO, World Health Organization, 2010. The First WHO Report on Neglected Tropical Disease Working to Overcome the Global Impact of Neglected Tropica Diseases. WHO http://whqlibdoc.who.int/publications/2010/9789241564090_ eng.pdf.

Wei, F., Zhong, S., Ma, Z., Kong, H., Medvec, A., Ahmed, R., Freeman, G.J., Krogsgaard, M., Riley, J.L., 2013. Strength of PD-1 signaling differentially affects T-cell effector functions. Proc. Natl. Acad. Sci. U. S. A. 110, E2480-2489.

Yamazaki, T., Akiba, H., Koyanagi, A., Azuma, M., Yagita, H., Okumura, K., 2005 Blockade of B7. H1 on macrophages supress $\mathrm{CD} 4^{+} \mathrm{T}$ cell proliferation by augmenting IFN $\gamma$-induced nitric oxide prodution. J. Immunol. 157, 1586-1591.

Zhang, Y., Zhou, Y., Lou, J., Li, J., Bo, L., Zhu, K., Wan, X., Deng, X., Cai, Z., 2010. PDL1 blockade improves survival in experimental sepsis by inhibiting lymphocyte apoptosis and reversing monocyte dysfunction. Crit. Care, http://dx.doi.org/10. $1186 /$ cc9354. 